\title{
Hepatitis B virus genotypes/subgenotypes in voluntary blood donors in Makassar, South Sulawesi, Indonesia
}

\author{
Andi Utama*1, Theresia I Octavia ${ }^{1}$, Rama Dhenni ${ }^{1}$, Upik A Miskad ${ }^{2}$, \\ Irawan Yusuf ${ }^{2}$ and Susan Tai ${ }^{1}$
}

Address: ${ }^{1}$ Molecular Epidemiology Division, Mochtar Riady Institute for Nanotechnology, Lippo Karawaci, Tangerang, Banten 15810, Indonesia and ${ }^{2}$ Faculty of Medicine, Hasanuddin University, Makassar, South Sulawesi 90245, Indonesia

Email: Andi Utama* - autama@mrinstitute.org; Theresia I Octavia - tioctavia@mrinstitute.org; Rama Dhenni - rdhenni@mrinstitute.org; Upik A Miskad - upik.miskad@telkom.net; Irawan Yusuf - irawanyusuf@yahoo.com; Susan Tai - stai@mrinstitute.org

* Corresponding author

Published: 19 August 2009

Virology Journal 2009, 6:128 doi:10.1 I86/1743-422X-6-128

This article is available from: http://www.virologyj.com/content/6/1//28

(C) 2009 Utama et al; licensee BioMed Central Ltd.

This is an Open Access article distributed under the terms of the Creative Commons Attribution License (http://creativecommons.org/licenses/by/2.0), which permits unrestricted use, distribution, and reproduction in any medium, provided the original work is properly cited.
Received: 23 June 2009

Accepted: 19 August 2009

\begin{abstract}
Background: Hepatitis $B$ virus (HBV) genotype appears to show varying geographic distribution. Molecular epidemiological study of HBV in particular areas in Indonesia is still limited. This study was aimed to identify the prevalence of HBV genotype/subgenotype and mutations in basal core promoter (BCP) region in voluntary blood donors in Makassar, one of the biggest cities in east part of Indonesia.

A total of $2 / 4$ hepatitis B surface antigen (HBsAg)-positive samples were enrolled in this study. HBV genotype/subgenotype was identified by genotype-specific PCR method or direct sequencing of pre-S region. Mutations in BCP were identified by direct sequencing of the corresponding region.

Results: $\mathrm{HBV} / \mathrm{B}$ and $\mathrm{HBV} / \mathrm{C}$ were detected in $61.21 \%$ and $25.23 \%$ of the samples, while mix of $\mathrm{HBV} / \mathrm{B}$ and $\mathrm{HBV} / \mathrm{C}$ was found in $12.62 \%$ of the samples. Based on pre-S region, among $\mathrm{HBV} / \mathrm{B}$ and $\mathrm{HBV} / \mathrm{C}, \mathrm{HBV} / \mathrm{B} 3$ (95.00\%) and $\mathrm{HBV} / \mathrm{Cl}$ (58.82\%) were predominant. Interestingly, HBV/D was identified in two samples (22.165.07 and 22.252.07). Complete genome sequences of two HBV/D strains (22.165.07 and 22.252.07) demonstrated that both strains belong to HBV/D6, and the divergence between the two strains were $1.45 \%$, while divergences of both 22.165 .07 and 22.252.07 strains with reference strain (AM422939/France) were $2.67 \%$. AI762T/GI764A mutation was observed in $1.96 \%$ and $5.36 \%$, whereas T1753V mutation was found in $2.94 \%$ and $1.79 \%$ of $\mathrm{HBV} / \mathrm{B}$ and $\mathrm{HBV} / \mathrm{C}$, respectively.
\end{abstract}

Conclusion: HBV/B and HBV/C are dominant in Makassar, similar to most areas in Indonesia. Mutations in BCP which might be associated with severity of liver disease are less common.

\section{Background}

Hepatitis B virus (HBV) infection is a major health problem leading to significant morbidity and mortality worldwide. Approximately, two billion people in the world have been infected by HBV [1]. The majority of acute HBV infections are self-limiting, whereas chronic HBV infection can cause chronic hepatitis, liver cirrhosis, or hepatocellular carcinoma. It is well known that Indonesia has a 
moderate to high endemicity of hepatitis B virus (HBV) infection [2], due to the lack of proper health facilities or poor economical status and less public awareness.

HBV, a member of the Hepadnaviridae, is a relaxed circular double-stranded DNA virus, and is currently classified into eight genotypes (A-H) based on a comparison of the entire HBV genomic sequence [3]. HBV genotypes appear to show varying geographic distribution. For instance, HBV/A is prevalent in Europe, Africa, and India $[4,5]$. HBV/B and HBV/C are predominant in most part of Asia, including China and Japan $[4,6]$. The HBV/D is common in the Mediterranean area, the Middle East and India, whereas the HBV/E is localized in sub-Saharan Africa [410]. The HBV/F and HBV/H is only identified in Central and South America [4,11-13]. The HBV/G has been found in France, Germany and United States [14-16].

Molecular epidemiological studies of HBV, either a nationwide study or study on particular areas in Indonesia, have shown that $\mathrm{HBV} / \mathrm{B}$ and $\mathrm{HBV} / \mathrm{C}$ are the most prevalent genotypes in Indonesia [2,17-20], although HBV/A and HBV/D have also been found in Eastern Indonesia, such as Moluccas and Papua $[19,20]$. Particularly in South Moluccas, the prevalence of HBV/D is high, ranging from $50-88 \%$ [20]. In the same study, analysis of 12 samples from Makassar demonstrated that only genotype B and C were found in the samples [20]. To date, there is no comprehensive study about HBV genotype prevalence as well as the genetic analysis of HBV circulated in Makassar. In this study, we have analyzed HBV genotype/subgenotype and mutations in BCP region from voluntary blood donors in Makassar, which is located in Wallace territory and the biggest city in Eastern Indonesia.

\section{Methods \\ Samples}

Serum samples from 214 blood donors (age 18-64 years, mean $30.9 \pm 10.3$ years, male/female 153/61) which were positive for HBsAg were collected in the Blood Transfusion Unit, Red Cross Makassar, South Sulawesi, Indonesia, between February and August 2007. HBsAg was determined by commercially available kit (AxSYM ${ }^{\circledast}$ HBsAg, Abbott Laboratories, Chicago, IL, USA). Blood samples were separated into sera and stored at $-70^{\circ} \mathrm{C}$ until use. The study was approved by the Institutional Ethic Committee and informed consent was obtained from each donor.

\section{Viral DNA extraction and genotyping}

HBV DNA was extracted from $200 \mu \mathrm{l}$ serum using QIAamp ${ }^{\circledast}$ DNA blood mini kit (Qiagen, Hilden, Germany) according to the manufacturer's instruction, and $50 \mu$ l eluted DNA was stored at $-70^{\circ} \mathrm{C}$ until use. HBV genotyping was performed by PCR using genotype specific primers as described by Naito et al. [21]. To avoid falsepositive results, instruction to prevent cross-contaminations were strictly followed, and results considered valid only when they were obtained in duplicate. Pre-S region was amplified by nested PCR using PCR Core System (Promega, Madison, WI, USA) and two sets of primers as previously described with minor modifications [22]. The first round PCR was performed for 35 cycles of $95^{\circ} \mathrm{C}$ for 1 $\min , 46.7^{\circ} \mathrm{C}$ for $30 \mathrm{~s}$ and $72^{\circ} \mathrm{C}$ for $1 \mathrm{~min}$. The second round PCR was carried out similar to the first round PCR, except with an annealing temperature of $44.6^{\circ} \mathrm{C}$. Primers PS1/PS2 and PS3/PS4 were used for the first and second rounds PCR, respectively. The PCR products were purified with Wizard ${ }^{\circledR}$ SV Gel and PCR Clean-Up System (Promega, Madison, WI, USA), directly sequenced employing an ABI 3130xl Genetic Analyzer (Applied Biosystems, Inc., Foster City, CA, USA) with the Big Dye Terminator V3.1 Cycle Sequencing kit (Applied Biosystems, Inc.) using primers $\mathrm{P} 3$ and P4. Multiple alignments of pre-S sequences were done using the CLUSTAL W method [23]. Phylogenetic trees were constructed using Neighbor-Joining method [24] with Kimura's two-parameter [25] and 1,000 replicates of bootstrap resampling as implemented in MEGA 4.1 [26]. Subgenotypes were assigned as described previously $[19,27,28]$.

\section{Full sequencing of $H B V$ genotype $D$}

The complete genome of HBV was amplified as 7 overlapping fragments (fragment 1-7) using nested-PCR with Go Taq PCR Core System (Promega). The list of primers and PCR products are shown in Table 1. First and second round PCR were performed for 35 cycles with same condition except for annealing temperature. The condition was as follow: denaturation at $95^{\circ} \mathrm{C}(5 \mathrm{~min})$, annealing at $48.1-57.4^{\circ} \mathrm{C}(30 \mathrm{~s})$ for the first round and $46.1-57.4^{\circ} \mathrm{C}$ $(30 \mathrm{~s})$ for the second round, and elongation at $72^{\circ} \mathrm{C}(1$ $\mathrm{min})$. PCR product was purified from agarose gel using Wizard $^{\circledR}$ SV Gel and PCR Clean-Up System (Promega), according to manufacturer's protocol, and directly sequenced. Percentage divergence of nucleotide sequences among HBV genotype D strain was calculated using MEGA 4.1 [26]. Phylogenetic trees were constructed similarly as in the pre-S sequences.

\section{BCP Mutations analysis}

BCP region was amplified by hemi-nested PCR using HBPr86/HBPr7 and HBPr87/HBPr 7 for two rounds PCR as previously described, with a slightly modified touchdown PCR [15]. The following cycling parameters were used for PCR: denaturation at $95^{\circ} \mathrm{C}(30 \mathrm{~s})$, annealing at $60.5-53.5^{\circ} \mathrm{C}(30 \mathrm{~s})$ and elongation at $72^{\circ} \mathrm{C}(30 \mathrm{~s})$. For the first 15 cycles, the annealing temperature was $60.5^{\circ} \mathrm{C}$; this temperature was then reduced by $0.5^{\circ} \mathrm{C}$ per cycle, and continued with constant annealing temperature for another 30 cycles. The first and second rounds PCR were 
Table I: Primers used for fragments amplification and sequencing of complete genome of HBV genotype D

\begin{tabular}{|c|c|c|c|c|c|}
\hline Fragment no. (bp) & Primers* & Polarity & Sequence $\left(5^{\prime} \rightarrow{ }^{\prime} 3\right)$ & Domain & Position \\
\hline \multirow[t]{3}{*}{ I (379) } & $\mathrm{HBPrI}$ & Forward & GGGTCACCATATTCTTGGG & HBPol & $2850-2860$ \\
\hline & HBPr2 & Forward & GAACAAGAGCTACAGCATGGG & HBPol/PreSI & $2867-2888$ \\
\hline & $\mathrm{HBPr} 3$ & Reverse & CCACTGCATGGCCTGAGGATG & PreSI/PreS2/HBPol & $3226-3246$ \\
\hline \multirow[t]{3}{*}{$2(891)$} & HBPrl4 & Forward & TGGGGTGGAGCCCTCAG & PreSI/HBPol & $3104-3120$ \\
\hline & HBPr94 & Reverse & GGTAWAAAGGGACTCAMGATG & $\mathrm{HBPol} / \mathrm{HBsAg}$ & 775-795 \\
\hline & $\mathrm{HBPr} \mid 35$ & Reverse & CARAGACAAAAGAAAATTGG & $\mathrm{HBPol} / \mathrm{HBsAg}$ & $803-822$ \\
\hline \multirow[t]{3}{*}{$3(54 I)$} & HBPr440 & Forward & TATGGATGATGTGGTATTGGG & $\mathrm{HBPol} / \mathrm{HBsAg}$ & $738-758$ \\
\hline & HBPrII3 & Reverse & CCGGCAGATGAGAAGGCACAGACGG & $\mathrm{HBX} / \mathrm{HBPol}$ & $1549-1574$ \\
\hline & HBPr374 & Reverse & GTTCCGCAGTATGGATCGGCAGAGG & HBPol & $1255-1279$ \\
\hline \multirow{2}{*}{$4(319)$} & HBPrIIO & Forward & ССTCTGCCGATCCATACTGCGGAAC & HBPol & $1255-1279$ \\
\hline & HBPrII3 & Reverse & CCGGCAGATGAGAAGGCACAGACGG & HBX/HBPol & $1549-1574$ \\
\hline \multirow[t]{3}{*}{$5(560)$} & $\mathrm{HBI}$ & Forward & GCCAAGTGTTTGCTGACGC & HBPol & $1174-1192$ \\
\hline & HB2 & Forward & CCATACTGCGGAACTCCTAG & HBPol & $1265-1284$ \\
\hline & HB3 & Reverse & AAAGTTGCATGGTGCTGGTG & $\mathrm{HBX}$ & $1803-1822$ \\
\hline \multirow[t]{3}{*}{$6(726)$} & HBPr86 & Forward & ACATAAGAGGACTCTTGGAC & HBX & $|652-| 67 \mid$ \\
\hline & HBPr87 & Forward & TACTTCAAAGACTGTGTGTTTA & $\mathrm{HBX}$ & $1704-1723$ \\
\hline & HBPrIII & Reverse & CTGCGAGGCGAGGGAGTTCTTCTTC & Core/HBPol & $2406-2430$ \\
\hline \multirow[t]{3}{*}{$7(585)$} & HBPr33 & Reverse & CTGAGGGCTCCACCCCA & PreSI/HBPol & $3104-3120$ \\
\hline & HBPr446 & Forward & GGAGTGTGGATTCGCACTCC & Core & $2303-2323$ \\
\hline & HBPr448 & Reverse & CCCATGCTGTAGCTCTTGTTC & HBPol/PreSI & $2868-2888$ \\
\hline
\end{tabular}

* All primers, except $\mathrm{HBI}-\mathrm{HB} 3$, were same as previous report [I5].

performed similarly except for annealing temperature $\left(58.5-51.5^{\circ} \mathrm{C}\right)$. The PCR products were purified with Wiz$\operatorname{ard}^{\circledast}$ SV Gel and PCR Clean-Up System (Promega) and directly sequenced using primer HBPr7. Multiple alignments of BCP sequences were done using the same method as in the pre-S sequences.

\section{Results}

\section{HBV genotype prevalence}

Of the 214 subjects enrolled in this study, 156 samples (72.90\%) could be genotyped by genotype-specific PCR, whereas 58 samples $(27.10 \%)$ could not. Based on this method, it was found that 91 samples (58.33\%) were $\mathrm{HBV} / \mathrm{B}, 37$ samples $(23.72 \%)$ were $\mathrm{HBV} / \mathrm{C}, 27$ samples $(17.31 \%)$ were mix of $\mathrm{HBV} / \mathrm{B}$ and $\mathrm{HBV} / \mathrm{C}$, and one sample $(0.64 \%)$ was HBV/D (Table 2$)$. For 58 samples that could not be identified by genotype-specific PCR, the pre$S$ region was amplified and directly sequenced. Of 58 samples, 40 samples $(68.97 \%)$ were $\mathrm{HBV} / \mathrm{B}$, and 38 of those $\mathrm{HBV} / \mathrm{B}(95.00 \%$ of $\mathrm{HBV} / \mathrm{B}$ or $65.52 \%$ of all samples) were $\mathrm{HBV} / \mathrm{B} 3$ and the other two isolates were HBV/B5 (Fig. 1, Table 2). Seventeen (29.31\%) of 58 samples were $\mathrm{HBV} / \mathrm{C}$, which was divided into $\mathrm{HBV} / \mathrm{C} 1$ (58.82\% of $\mathrm{HBV} / \mathrm{C}$ or $17.24 \%$ of all samples) and HBV/C2 (41.18\% of HBV/C or $12.07 \%$ of all samples). In addition, HBV/D was only found in one sample. From HBV genotyping based on both genotype-specific PCR and pre-S sequence on 214 blood donors, it was shown that HBV/B was predominant (131 samples, 61.21\%), followed by HBV/C (54 samples, $25.23 \%)$, mix of $\mathrm{HBV} / \mathrm{B}$ and $\mathrm{HBV} / \mathrm{C}$ (27 samples, $12.62 \%$ ), and HBV/D (2 samples, 0.93\%) (Table 2).

\section{Full sequence of $\mathrm{HBV}$ genotype $D$}

Since $\mathrm{HBV} / \mathrm{D}$ is rare in this area, we interested to analyze the complete genome of the two HBV/D strains (22.165.07 and 22.252.07) found in the samples. Phylogenetic analysis of complete genome, partial $\mathrm{S}$, and pre-C/ $\mathrm{C}$ regions confirmed that the two viruses were HBV/D6 (Fig. 2). Percentage divergences of complete genome, pre$\mathrm{S} / \mathrm{S}, \mathrm{X}$, pre-C/C, and Pol genes among the two strains were $1.45 \%, 1.45 \%, 1.40 \%, 0.43 \%$, and $2.19 \%$, respectively. Based on the complete genome, divergences of 22.165.07 strain with reference strains, AM422939 (France), AB493846 (Papua), and AB493845 (Papua) were 2.67\%, $1.44 \%$ and $2.03 \%$, respectively (Table 3 ). Similarly, another strain (22.252.07) showed $2.67 \%, 1.18 \%$, and $1.90 \%$ divergences with those three reference strains. Based on each gene, the two present strains demonstrated high identity with $\underline{A B} 493846$ (Papua) in $\mathrm{X}$ genes, with identity of $99.57-100.00 \%$, but less homology with 


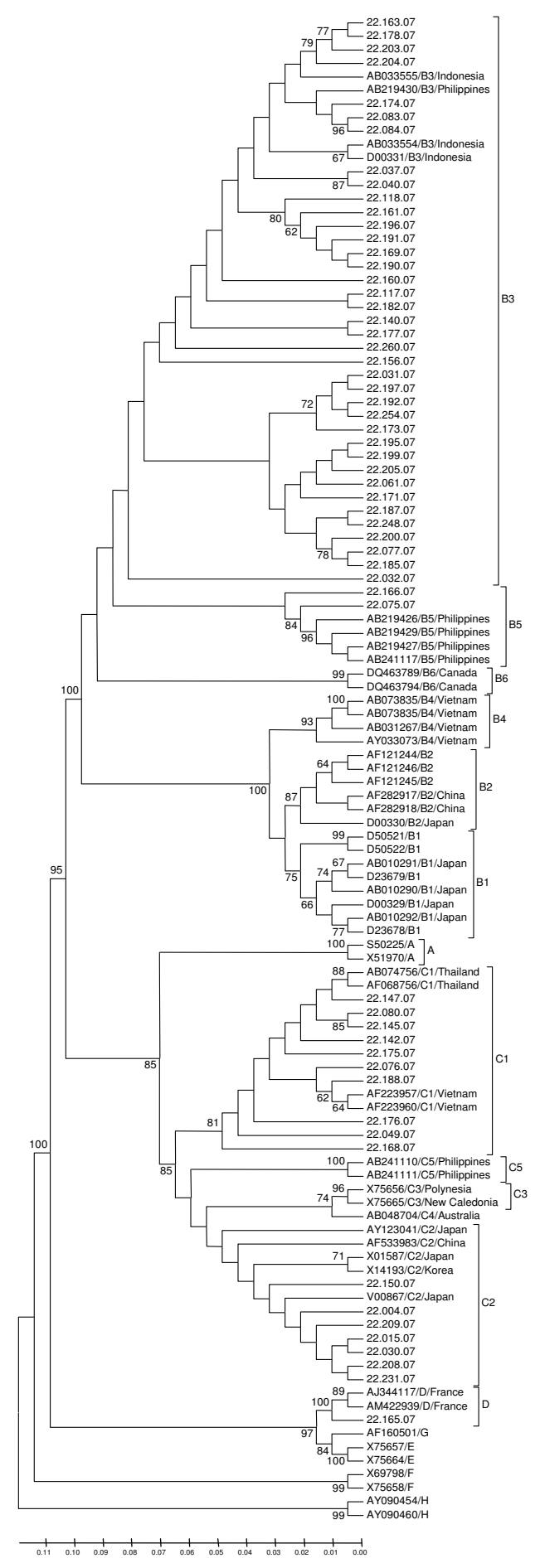

Figure I

Phylogenetic analysis of pre-S region of HBV. Phylogenetic tree was constructed from the pre-S sequences of 58 samples (accession number EU926161-EU926217) together with sequences retrieved from GenBank. 
Table 2: HBV genotype analysis of samples based on genotype specific PCR and pre-S sequence.

\begin{tabular}{|c|c|c|c|}
\hline \multirow[b]{2}{*}{ Genotype/Subgenotype } & \multicolumn{3}{|c|}{ No. (\%) based on } \\
\hline & Genotype-specific PCR & Pre-S sequence & All \\
\hline B & 91 (58.33) & $40(68.97)$ & $|3|(6|.2|)$ \\
\hline B3 & & $38(65.52)$ & \\
\hline B5 & & $2(3.45)$ & \\
\hline C & $37(23.72)$ & $17(29.31)$ & $54(25.23)$ \\
\hline $\mathrm{Cl}$ & & $10(17.24)$ & \\
\hline $\mathrm{C} 2$ & & 7 (12.07) & \\
\hline$B+C$ & $27(|7.3|)$ & $0(0.00)$ & $27(12.62)$ \\
\hline D & I (0.64) & I (I.72) & $2(0.93)$ \\
\hline Total & $156(100.00)$ & $58(100.00)$ & $214(100.00)$ \\
\hline
\end{tabular}

AM422939 (France) in pre-C/C region, which showed only $95.62 \%$ identity (Table 3 ).

\section{Genetic variation in $\mathrm{BCP}$ region}

In order to find out specific nucleotide substitution among HBV in the subjects, BCP region was analyzed. Of 214 samples, 169 were positive for PCR and sequencing, however 9 samples could not be analyzed due to incomplete data. BCP sequence of HBV/B (102 samples), HBV/ C (56 samples), and HBV/D (2 samples) were respectively aligned. It was observed that overall nucleotide substitution was rarely occurred in all genotypes. Double mutation (A1762T/G1764A), one of significant mutations associated with advanced liver disease including HCC, was only found in $1.96 \%(2 / 102)$ of HBV/B (Fig. 3). Likewise, the double mutation was only observed in $5.36 \%$ (3/56) of HBV/C (Fig. 3). Analysis of nucleotide at position 1753 showed that a T-to-V (A/G/C) mutation, which also suggested having association with liver disease progression, was found as much as $2.94 \%$ (3/102) and $1.79 \%$ $(1 / 56)$ in HBV/B and HBV/C, respectively. None of these mutations was identified in HBV/D (Fig. 3). However, a G-to-A substitution at nucleotide 1896, which prevents the production of HBeAg by introducing a premature stop codon into the open reading frame of the pre- $\mathrm{C}$ region, was found in both strains of HBV/D (data not shown).

\section{Discussion}

The present study demonstrates that HBV/B (61.21\%) and HBV/C (25.23\%) were the most prevalent among HBsAgpositive blood donors in Makassar, South Sulawesi, although HBV/D was also rarely found in the samples. Analysis of pre-S sequence of 58 samples revealed that in $\mathrm{HBV} / \mathrm{B}$ the percentage of HBV/B3 was much higher than HBV/B5. In HBV/C, on the other hand, HBV/C1 and HBV/ $\mathrm{C} 2$ were detected with similar frequency.

HBV/B3 is widely distributed in Indonesia, but has not been reported in other countries, suggesting that HBV/B3 is indigenous to Indonesia [20]. The HBV types we found in Makassar are similar to those reported in previous studies from several areas in Indonesia [2,17-19], but the frequencies are different to Papua and Moluccas in where $\mathrm{HBV} / \mathrm{C}$ is more dominant $[19,20]$. In addition, no HBV/A was found in Makassar, although it was found in Balikpapan and Kupang [20].

Several studies have reported the prevalence of HBV genotype from blood donors in the southern Asian region. A study from Thailand demonstrated that HBV/A, HBV/B and $\mathrm{HBV} / \mathrm{C}$ were detected among blood donors, where $\mathrm{HBV} / \mathrm{C}(89.3 \%)$ was the most prevalent compared to HBV/B (7.4\%) and HBV/A (0.5\%) [29]. Although this study did not identify the subgenotype, complete genome analysis of HBV/C from Thailand and some other countries which are geographically close to Indonesia such as Vietnam and Myanmar showed that most of HBV/C was classified into HBV/C1 [28], whereas in Makassar HBV/C1 and $\mathrm{HBV} / \mathrm{C} 2$ were dominant. On the other hand, analysis of asymptomatic HBV carriers from the Philippines showed that the prevalence of $\mathrm{HBV} / \mathrm{B}, \mathrm{HBV} / \mathrm{C}, \mathrm{HBV} / \mathrm{D}$, mix of HBV/B and HBV/D, and HBV/A were 53.4, 21.4, $14.3,7.1$, and $3.6 \%$, respectively [30]. In general, the percentage of HBV/B in the Philippines was similar to that in Makassar, although it is not possible to compare the subgenotypes with the available data. However, all HBV/C strains in the Philippines samples were classified into HBV/C5, which is different with subgenotypes circulated in Makassar (HBV/C1 and HBV/C2). A study from Malaysia using small number of healthy blood donors and chronic hepatitis B carriers demonstrated that HBV/C, $\mathrm{HBV} / \mathrm{B}$, and HBV/D were identified in the samples [31], which is quite similar to our findings in Makassar.

Studies from India demonstrated that the distribution of HBV genotype in blood donors was slightly different between Eastern and Southern India. In Eastern India, beside the major HBV genotypes transmitted in India such 

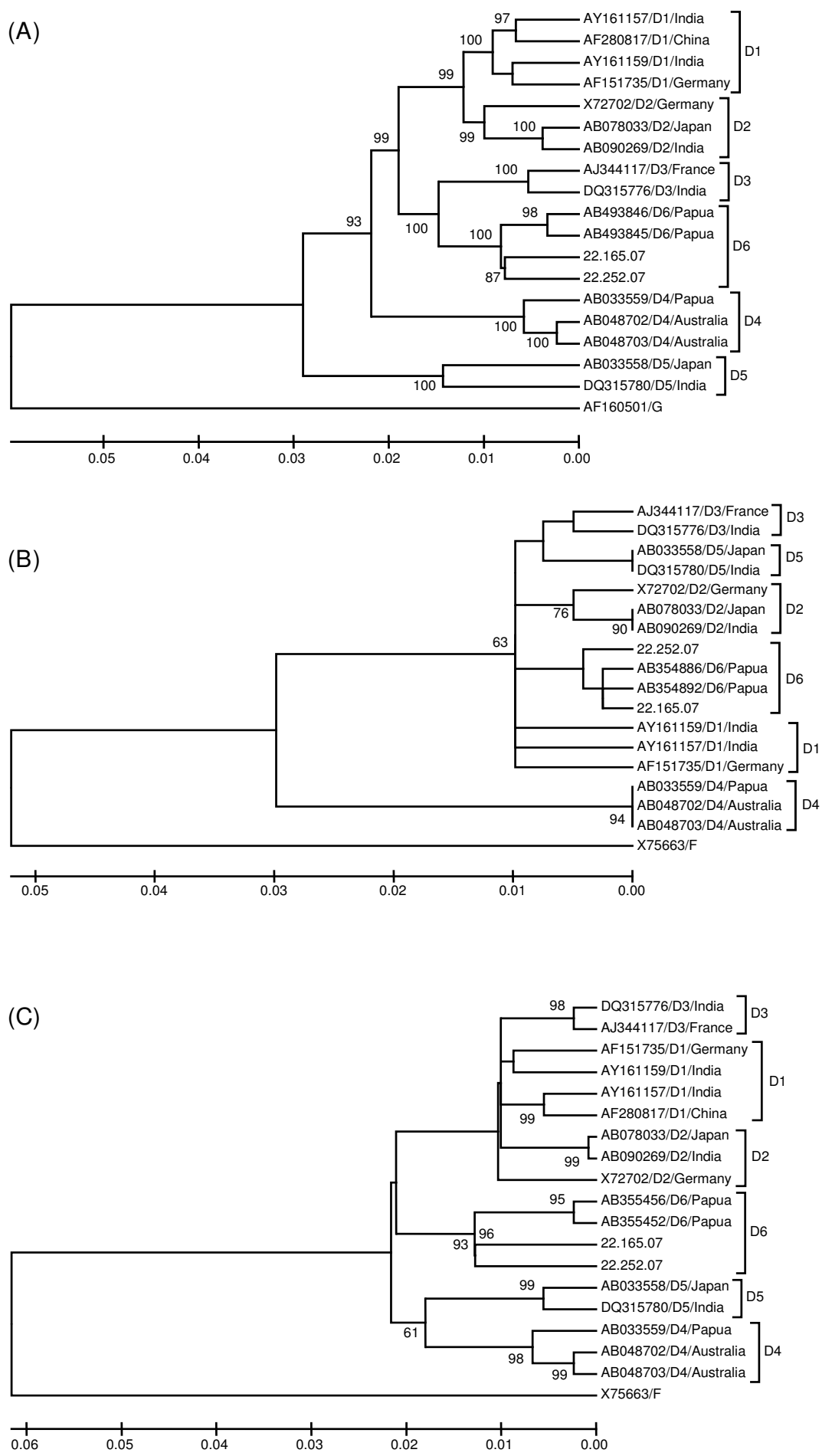

Figure 2

Phylogenetic analysis of complete genome (A), partial S (B) and pre-C/C (C) of HBV/D isolate 22.165.07 and 22.252.07 (accession number EU921418 and EU921419). Phylogenetic trees were constructed from sequences of each region of HBV genome from the samples and sequences retrieved from GenBank. The sequences used for partial S and pre-C/ C were nucleotide no. 500-703 and 1814-2452, respectively, as described in previous report [19]. 
Table 3: Percentage divergences of nucleotide sequences between present and reference strains

\begin{tabular}{|c|c|c|c|c|c|c|c|c|}
\hline \multirow[b]{2}{*}{ Region } & \multicolumn{4}{|c|}{22.165 .07} & \multicolumn{4}{|c|}{ 22.252.07 } \\
\hline & 22.252 .07 & $\frac{\text { AM422939 }}{\text { (France) }}$ & $\frac{\mathrm{AB} 493846}{\text { (Papua) }}$ & $\frac{\mathrm{AB} 493845}{\text { (Papua) }}$ & 22.165 .07 & $\frac{\text { AM422939 }}{\text { (France) }}$ & $\frac{\text { AB493846 }}{\text { (Papua) }}$ & $\frac{\mathrm{AB} 493845}{\text { (Papua) }}$ \\
\hline $\begin{array}{l}\text { Complete } \\
\text { Genome }\end{array}$ & 1.45 & 2.67 & 1.44 & 2.03 & 1.45 & 2.67 & 1.18 & 1.90 \\
\hline Pre-S/S & 1.45 & 1.79 & 2.55 & 2.55 & 1.45 & 1.88 & 2.39 & 2.71 \\
\hline Polymerase & 1.40 & 2.16 & 1.25 & 1.65 & 1.40 & 2.20 & 1.02 & 1.57 \\
\hline$X$ gene & 0.43 & 1.72 & 0.43 & 2.45 & 0.43 & 1.29 & 0.00 & 2.00 \\
\hline Pre-C/C & 2.19 & 4.38 & 1.23 & 2.13 & 2.19 & 4.38 & 0.97 & 1.95 \\
\hline
\end{tabular}

as $\mathrm{HBV} / \mathrm{D}(56.0 \%)$ and $\mathrm{HBV} / \mathrm{A}(20.6 \%)$, quite high percentage of $\mathrm{HBV} / \mathrm{C}(23.4 \%)$ was also found in the blood donors [32]. Phylogenetic analysis revealed that those $\mathrm{HBV} / \mathrm{C}$ strains that clustered with $\mathrm{HBV} / \mathrm{C}$ found in SouthEast Asia including Indonesia were classified as HBV/C1 [32]. On the other hand, in Southern India, only HBV/D (76.11\%) and HBV/A (11.94\%) were detected [33], similar to the HBV genotype distribution pattern in Northern and Western India [5].

In China, $\mathrm{HBV} / \mathrm{C}$ was detected in high percentage $(68.0 \%)$ from blood donors along with HBV/B (25.8\%), HBV/A (2.1\%) and mix HBV/B and HBV/C (4.1\%), although the subgenotype was not identified in this study [34]. Thus, in general, the distribution of HBV genotype from blood donors in Makassar is different to that in India and China.

Prior to our study, in Indonesia HBV/D has only previously been found in Papua and Moluccas $[19,20]$. Therefore, we were interested to analyze the complete genome of the two HBV/D strains (22.165.07 and 22.252.07) found in our samples from Makassar. Phylogenetic analysis of complete genome, partial $\mathrm{S}$, and pre- $\mathrm{C} / \mathrm{C}$ regions confirmed that the two HBV/D strains were subgenotype D6 (Fig. 2). The present HBV/D strains were then compared with two references recently published from Papua
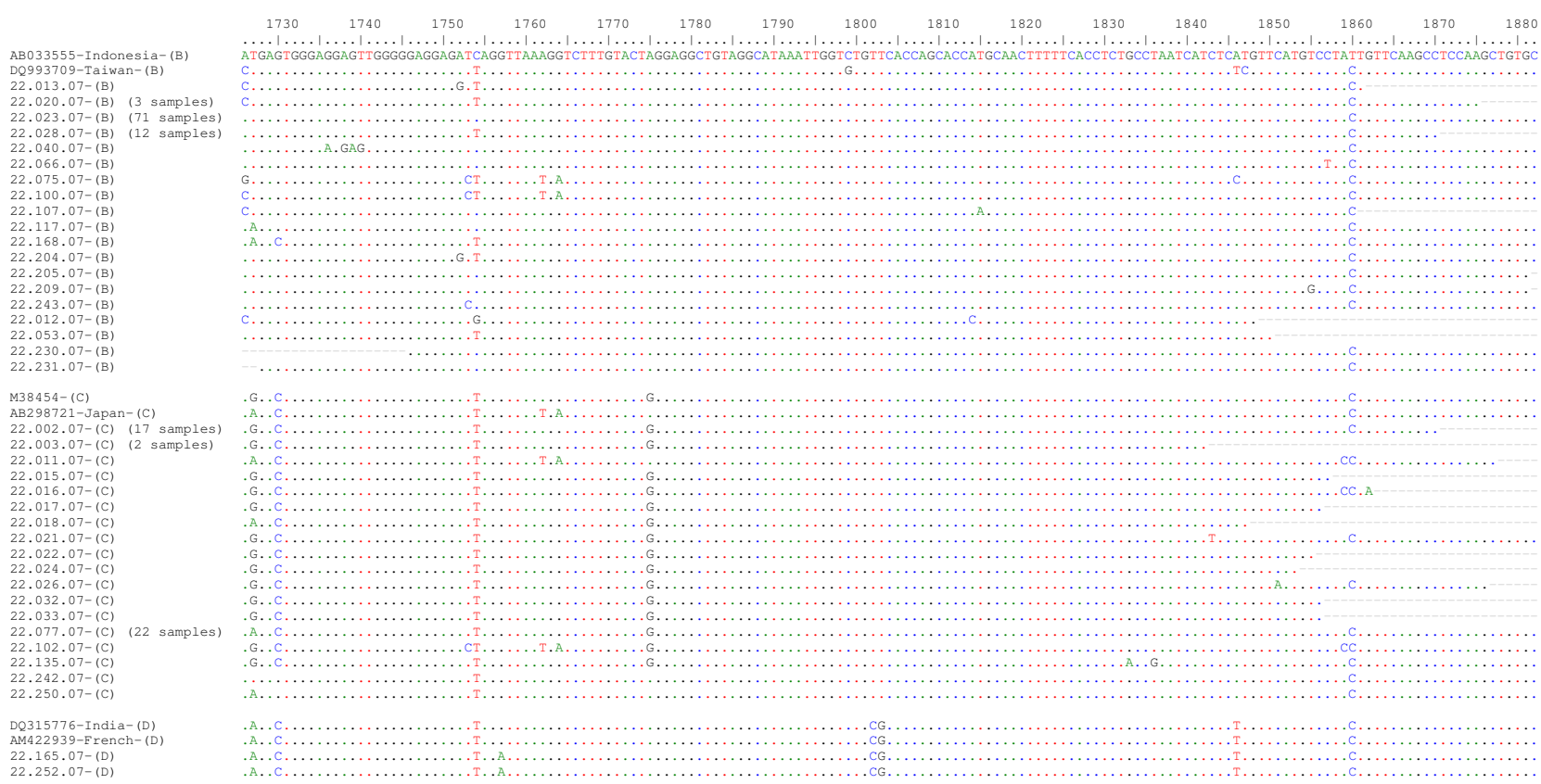

Figure 3

Alignment of BCP sequences. The BCP sequences of HBV/B of 102 samples (accession number EU938I43-EU938244), $\mathrm{HBV} / \mathrm{C}$ of 56 samples (accession number EU938245-EU938300), and HBV/D of 2 samples (accession number EU92I4I8 and EU921419) were aligned. 
( $\underline{A B 493846}$ and $\underline{A B 493846)}$ ) and one reference which found in France (AM422939). Based on the complete genome, divergences between the present strains and Papua strains (HBV/D6) were lower than the divergence between the two strains and France strain (HBV/D3) (Fig. 2). Thus, it is confirmed that the HBV/D found in Makassar was the same with the HBV/D strains present in Papua (HBV/D6) [19]. Because a previous study found HBV/D strains in Moluccas were HBV/D1 and HBV/D3 [20], it is possible that the HBV/D found in Makassar has been imported from Papua, not Moluccas, even though Moluccas is very close to Makassar.

Many studies have demonstrated that HBV mutations, including mutations in BCP region, are linked with the severity and outcome of HBV infection [35-37]. Our recent data also revealed that mutations in $\mathrm{BCP}$ were associated with clinical outcome of liver disease [38]. We therefore looked for mutations in the $\mathrm{BCP}$ region. Double mutation (A1762T/G1764A) was only found in $1.96 \%$ of HBV/B (Fig. 3). Likewise, the double mutation was only observed in $5.36 \%$ of HBV/C (Fig. 3). Analysis of the nucleotide at position 1753 showed that a T-to-V (A/G/C) mutation, which has also been associated with HCC development [39], was found to be less frequent in both $\mathrm{HBV} / \mathrm{B}$ and HBV/C (2.94\% and 1.79, respectively). None of these mutations was identified in HBV/D (Fig. 3). Hence, our results demonstrated that the frequency of mutations in BCP in blood donors in Makassar was low. In our previous study, we included $15 \mathrm{HBV}$-associated liver disease samples from Makassar [38], and found that the prevalence of $\mathrm{T} 1753 \mathrm{~V}$ and $\mathrm{A} 1762 \mathrm{~T} / \mathrm{G} 1764 \mathrm{~A}$ mutations were $40.0 \%$ and $60.0 \%$, respectively, suggesting that those mutations were associated with severity of liver disease. Since both T1753V and A1762T/G1764A mutations were less common in blood donors, the chance of developing severe liver disease might be relatively low in the blood donors in Makassar.

In comparison, a study from Indian blood donors showed that the occurrence of double mutation in BCP was extremely high in $\mathrm{HBV} / \mathrm{C}(72.4 \%)$ and relatively high in HBV/A (24.1\%) and HBV/D (21.5\%) [32]. Another study also reported that K130M and V131I substitutions, which are corresponding to double mutation in $\mathrm{BCP}$, from Indian inactive carrier were generally high $(36.0 \%)$ [40]. However, they found that the occurrence of other mutations suggested to have associated with HCC was low [40]. If BCP mutation is strongly associated with clinical outcome of liver disease including HCC, the incidence of HCC must be high in India. In fact, the HCC incidence was very low in India [41], thus the association of BCP mutations as well as other mutations with severity of liver disease might be not depend only on virus mutations, but also host factors, and therefore needs further investigation.

\section{Conclusion}

$\mathrm{HBV} / \mathrm{B}$ and HBV/C are dominant in Makassar, similar with the HBV genotype distribution in most areas in Indonesia. Mutations in BCP which might be associated with severity of liver disease are less common.

\section{Competing interests}

The authors declare that they have no competing interests.

\section{Authors' contributions}

Conceived of the study, participated in its design and coordination, drafted the manuscript and coordinate the whole work team: AU. Carried out the molecular genotyping study: TIO. Responsible for sample and clinical data collection, and contributed in data analysis: RD. Participated in sample and clinical data collection: UAM. Participated in the editing the manuscript and clinical data: IY. Coordinated the research effort and participated in manuscript preparation: ST. All authors have read and approved the final manuscript.

\section{Acknowledgements}

We thank Mardiana Radjuni for sample collection and Dr. David Vaux (La Trobe University, Australia) for critical reading of the manuscript. This work was supported by MRIN Research Funding (Budget no. cc042/2007).

\section{References}

I. Zuckerman JN, Zuckerman AJ: Current topics in hepatitis B. J Infect 2000, 4I: I30-I 36.

2. Sastrosoewignjo RI, Sandjaja B, Okamoto H: Molecular epidemiology of hepatitis B virus in Indonesia. J Gastroenterol Hepatol |99|, 6:49|-498.

3. Kidd-Ljunggren K, Miyakawa $\mathrm{Y}$, Kidd $\mathrm{AH}$ : Genetic variability in hepatitis B viruses. J Gen Virol 2002, 83: | 267- 1280.

4. Liu WC, Phiet PH, Chiang TY, Sun KT, Kung KH, Young KC, Wu IC, Cheng PN, Chang TT: Five subgenotypes of hepatitis B virus genotype B with distinct geographic and virological distribution. Virus Res 2007, I 29:2 I2-223.

5. Datta S: An overview of molecular epidemiology of hepatitis B virus (HBV) in India. Virol J 2008, 5:156.

6. Orito E, Ichida T, Sakugawa H, Sata M, Horiike N, Hino K, Okita K, Okanoue T, lino S, Tanaka E, Suzuki K, Watanabe H, Hige S, Mizokami M: Geographic distribution of hepatitis B virus (HBV) genotype in patients with chronic HBV infection of Japan. Hepatology 200I, 34:590-594.

7. Alam MM, Zaidi SZ, Malik SA, Shaukat S, Naeem A, Sharif S, Angez M, Butt JA: Molecular epidemiology of hepatitis B virus genotypes in Pakistan. BMC Infect Dis 2007, 7: 115.

8. Fujiwara K, Tanaka $Y$, Orito E, Ohno T, Kato T, Sugihara K, Hasegawa I, Sakurai M, Ito K, Ozasa A, Sakamoto Y, Arita I, El-Gohary A, Benoit A, Ogoundele-Akplogan SI, Yoshihara N, Ueda R, Mizokami M: Distribution of HBV genotypes among HBV carriers in Benin: phylogenetic analysis and virological characteristics of HBV genotype E. World / Gastroenterol 2005, I I:6410-64I5.

9. Kurbanov F, Tanaka Y, Fujiwara K, Sugauchi F, Mbanya D, Zekeng L, Ndembi N, Ngansop C, Kaptue L, Miura T, Ido E, Hayami M, Ichimura $H$, Mizokami M: A new subtype (subgenotype) Ac (A3) of hepatitis $B$ virus and recombination between genotypes $A$ and $E$ in Cameroon. J Gen Virol 2005, 86:2047-2056.

10. Zekri ARN, Hafez MM, Mohamed NI, Hassan ZK, El-Sayed MH, Khaled MM, Mansour T: Hepatitis B virus (HBV) genotypes in Egyptian pediatric cancer patients with acute and chronic active HBV infection. Virol J 2007, 4:74. 
11. Arauz-Ruiz P, Norder H, Robertson BH, Magnius LO: Genotype H: a new Amerindian genotype of hepatitis $B$ virus revealed in Central America. J Gen Virol 2002, 83:2059-2073.

I2. Livingston SE, Simonetti JP, McMahon BJ, Bulkow LR, Hurlburt KJ, Homan CE, Snowball MM, Cagle HH, Williams JL, Chulanov VP: Hepatitis $B$ virus genotypes in Alaska native people with hepatocellular carcinoma: Preponderance of Genotype F. J Infect Dis 2007, 195:5-II.

13. Nakano T, Lu L, Hu X, Mizokami M, Orito E, Shapiro CN, Hadler SC, Robertson BH: Characterization of hepatitis B virus genotypes among Yucpa Indians in Venezuela. J Gen Virol 200I, 82:359-365.

14. Chu CJ, Keeffe EB, Han SH, Perrillo RP, Min AD, Soldevila-Pico C, Carey W, Brown RS Jr, Luketic VA, Terrault N, Lok AS: Hepatitis B virus genotypes in the United States; results of nationwide study. Gastroenterol 2003, I 25:444-45 I.

15. Stuyver L, De Gendt S, Van Geyt C, Zoulim F, Fried M, Schinazi RF, Rossau R: A new genotype of hepatitis B virus: complete genome and phylogenetic relatedness. J Gen Virol 2000, $8 \mathrm{I}: 67-74$.

16. Vieth S, Manegold C, Drosten C, Nippraschk T, Gunther S: Sequence and phylogenetic analysis of hepatitis $B$ virus genotype $\mathbf{G}$ isolated in Germany. Virus Genes 2002, 24:153-156.

17. Lusida MI, Surayah, Sakugawa H, Nagano-Fujii M, Mulyanto, Handajani R, Boediwarsono, Setiawan PB, Nidom CA, Ohgimoto S, Hotta $\mathrm{H}$ : Genotype and subtype analyses of hepatitis B virus (HBV) and possible co-infection of $H B V$ and hepatitis $C$ virus (HCV) or hepatitis D virus (HDV) in blood donors, patients with chronic liver disease and patients on hemodialysis in Surabaya, Indonesia. Microbiol Immunol 2003, 47:969-975.

18. Nurainy N, Muljono DH, Sudoyo H, Marzuki S: Genetic study of hepatitis B virus in Indonesia reveals a new subgenotype of genotype B in east Nusa Tenggara. Arch Virol 2008, 153:1057-1065.

19. Lusida MI, Nugrahaputra VE, Soetjipto, Handajani R, Nagano-Fujii M, Sasayama M, Utsumi T, Hotta H: Novel subgenotypes of hepatitis B virus genotype $\mathbf{C}$ and $\mathbf{D}$ in Papua, Indonesia. J Clin Microbio 2008, 46:2160-2166

20. Mulyanto, Depamede SN, Surayah K, Tsuda F, Ichiyama K, Takahashi $\mathrm{M}$, Okamoto $\mathrm{H}$ : A nationwide molecular epidemiological study of hepatitis B virus in Indonesia: identification of two novel subgenotypes, B8 and C7. Arch Virol 2009, 154:1047-1059.

21. Naito H, Hayashi S, Abe K: Rapid and specific genotyping system for hepatitis B virus corresponding to six major genotypes by PCR using type-specific primers. I Clin Microbiol 200I, 39:362-364.

22. Chen BF, Liu CJ, Jow GM, Chen PJ, Kao JH, Chen DS: Evolution of hepatitis $B$ virus in an acute hepatitis $B$ patient co-infected with genotype B and C. J Gen Virol 2006, 87:39-49.

23. Thompson JD, Higgins DG, Gibson TJ: CLUSTAL W: improving the sensitivity of progressive multiple sequence alignment through sequence weighting, position-specific gap penalties and weight matrix choice. Nucleic Acids Res 1994, 22:4673-4680.

24. Saitou N, Nei M: The neighbor-joining method: A new method for reconstructing phylogenetic trees. Mol Biol Evol 1987, 4:406-425.

25. Kimura M: A simple method for estimating evolutionary rate of base substitutions through comparative studies of nucleotide sequences. I Mol Evol 1980, I6: I I I- I20.

26. Tamura K, Dudley J, Nei M, Kumar S: MEGA4: Molecular Evolutionary Genetics Analysis (MEGA) software version 4.0. Mol Biol Evol 2007, 24:1596-1599.

27. Norder H, Couroucé AM, Coursaget P, Echevarria JM, Lee SD, Mushahwar IK, Robertson BH, Locarnini S, Magnius LO: Genetic diversity of hepatitis $B$ virus strains derived worldwide: genotypes, subgenotypes, and HBsAg subtypes. Intervirology 2004, 47:289-309.

28. Banerjee A, Kurbanov F, Datta S, Chandra PK, Tanaka Y, Mizokami M, Chakravarty R: Phylogenetic relatedness and genetic diversity of hepatitis B virus isolates in Eastern India. I Med Virol 2006, 78: II64-II74

29. Jutavijiitum $P$, Jiviriyawat $Y$, Yousukh $A$, Kunachiwa W, Toriyama $K$ : Genotypes of hepatitis B virus among voluntary blood donors in northern Thailand. Hepatol Res 2006, 35:263-266.

30. Cavinta L, Sun J, May A, Yin J, von Meltzer M, Radtke M, Barzaga NG, Cao G, Schaefer S: A new isolate of hepatitis B virus from the
Philippines possibly representing a new subgenotype C6. Med Virol 2009, 81 :983-987.

31. Ong HT, Duraisamy G, Peng NK, Siang TW, Seow HF: Genotyping of hepatitis B virus in Malaysia based on the nucleotide sequence of preS and S genes. Microbes Infect 2005, 7:494-500.

32. Biswas A, Chandra PK, Datta S, Panigrahi R, Banerjee A, Chakrabarti S, Biswas K, Patra D, Bhattacharya P, Biswas K, Chakravarty R: Frequency and distribution of hepatitis $B$ virus genotypes among eastern India voluntary blood donors: Association with precore and basal core promoter mutations. Hepatol Res 2009, 39:53-59.

33. Vivekanandan A, Abraham P, Sridharan G, Chandy G, Daniel D, Raghuraman S, Daniel HD, Subramaniam T: Distribution of hepatitis $B$ virus genotypes in blood donors and chronically infected patients in a tertiary care hospital in Southern India. Clin Infect Dis 2004, 38:e8I-e86.

34. Li HQ, Li Z, Liu Y, Li JH, Dong JQ, Gao JR, Gou CY, li H: Association of polymorphism of tumor necrosis factor-alpha gene promoter region with outcome of hepatitis $B$ virus infection. World J Gastroenterol 2005, I I:52 I3-52 I 7.

35. Hunt CM, McGill JM, Allen MI, Condreay LD: Clinical relevance of hepatitis B viral mutations. Hepatology 2000, 31:1037-1044.

36. Jammeh S, Tavner F, Watson R, Thomas HC, Karayiannis P: Effect of basal core promoter and pre-core mutations on hepatitis $B$ virus replication. J Gen Virol 2008, 89:90I-909.

37. Liu CJ, Kao JH, Lai MY, Chen PJ, Chen DS: Precore/core promoter mutations and genotypes of hepatitis $B$ virus in chronic hepatitis $B$ patients with fulminant or subfulminant hepatitis. J Med Virol 2004, 72:545-550.

38. Utama A, Purwantomo S, Siburian MD, Dhenni R, Gani RA, Hasan I, Sanityoso A, Miskad UA, Akil F, Yusuf I, Achwan WA, Soemohardjo S, Lelosutan SAR, Martamala R, Lukito B, Budihusodo U, Lesmana LA, Sulaiman A, Tai S: Hepatitis $B$ virus genotypes and basal core promoter mutations in Indonesia. World J Gastroenterol 2009, 15:4028-4036.

39. Takahashi K, Ohta $\mathrm{Y}$, Kanai K, Akahane $\mathrm{Y}$, Iwasa $\mathrm{Y}$, Hino K, Ohno N, Yoshizawa H, Mishiro S: Clinical implications of mutations C-toTI653 and T-to-C/A/GI753 of hepatitis B virus genotype C genome in chronic liver disease. Arch Virol 1999, 144: 1299-1 308

40. Datta S, Baneriee A, Chandra PK, Biswas A, Panigrahi R, Mahapatra PK, Panda CK, Chakrabarti S, Bhattacharya SK, Chakravarty R: Anal$y$ sis of hepatitis $B$ virus $X$ gene phylogeny, genetic variability and its impact on pathogenesis: implication in eastern Indian HBV carriers. Virology 2008, 382:190-198.

4I. Hussain SP, Schwank J, Staib F, Wang XW, Harris CC: TP53 mutations and hepatocellular carcinoma: insights into the etiology and pathogenesis of liver cancer. Oncogene 2007, 26:2166-2176.

Publish with Bio Med Central and every scientist can read your work free of charge

"BioMed Central will be the most significant development for disseminating the results of biomedical research in our lifetime. "

Sir Paul Nurse, Cancer Research UK

Your research papers will be:

- available free of charge to the entire biomedical community

- peer reviewed and published immediately upon acceptance

- cited in PubMed and archived on PubMed Central

- yours - you keep the copyright 